Eduard Mühle:

\title{
Die Slawen im Mittelalter zwischen Idee und Wirklichkeit.
}

Wien - Köln - Weimar: Böhlau Verlag. 2020. 503 s.

ISBN 978-3-412-51898-1

Slavistiku čas od času trápí otázka, zda Slovany spojuje ještě něco jiného než to, že mluví slovanskými jazyky. Nyní má také k zodpovězení této otázky přispět objemná kniha Eduarda Mühleho o Slovanech ve středověku. Její obsah je následující. První kapitola je prolog - pojednává o zájmu o slovanské národy a země v novověku (1 Prolog: Die Erfindung der Slawen in der Neuzeit; s. 7-39). Pak následuje druhá kapitola, věnovaná otázkám, které si kniha klade (tedy zejména, zda slovanství představovalo ve středověku účinný dějinný faktor), a způsobům, jak položené otázky chce zodpovědět (2 Fragestellung und Vorgehen; s. 41-45). Nato přichází sedm jádrových kapitol. Ve třetí kapitole se píše o prvních zprávách o Slovanech v byzantských, latinských a orientálních pramenech 3 Die Entdeckung der Slawen im frühen Mittelalter; s. 47-81). Další kapitola pojednává o světě prehistorických Slovanů - o jejich poměrech sídelních, hospodářských, náboženských, sociálních (4 Frühslawische Lebenswelten; s. 83-133). Pátá kapitola má za téma první slovanské státní útvary - protobulharskou říši, západobalkánská knížectví, Korutany, Velkou Moravu ( 5 Erste slawische Herrschaftsbildungen; s. 135-170). V šesté kapitole se píše o vytváření samostatných slovanských národů - v Bulharsku, Čechách, Chorvatsku, Kyjevské Rusi, Polsku a Srbsku (6 Die Slawen im Prozess der mittelalterlichen Nationswerdung; s. 171-296). Sedmá kapitola pak naopak pojednává o slovanských oblastech, kde středověké národy vytvořeny nebyly - polabské, pomořské, balkánské ( $7 \mathrm{Ab}$ gebrochene Reichsbildungen und ausgebliebene Nationswerdungen; s. 297-346). Osmá kapitola líčí obraz středověkých Slovanů, jak jej podávají neslovanské středověké prameny - byzantské, arabsko-islámské a latinské (8 Die Slawen im nichtslawischen mittelalterlichen Weltbild; s. 347-380). Nakonec devátá kapitola pojednává o představách o slovanském společenství v pozdním středověku, a to v Čechách, Polsku, Pomořanech, jihovýchodní Evropě a v Kyjevské a Moskevské Rusi (9 Ideen von slawischer Gemeinschaft im späten Mittelalter; s. 381-436). Poslední kapitola je epilog, shrnující hlavní myšlenky práce (10 Epilog: Die Erfindung der Slawen im Mittelalter; s. 437-445).

Autor svou knihu asi začal špatně, totiž kapitolou nazvanou Die Erfindung der Slawen in der Neuzeit. Pak už je vlastně zbytečné hledat, zda existoval nějaký sociálně relevantní pojem Slovanů předtím, a podle toho vypadá i autorovo pojednání, uchylující se k výčtu potenciálních svědectví o existenci takového pojmu ve středověku a jejich mechanickému vyvracení. Nechceme snad říct, že práce je tedy zbytečná, ale domníváme se, že autor měl být méně rázný a přece jen opatrnější. Nepřihodilo by se mu pak možná, že například považuje zamítnutí kontinuity slovanského písemnictví mezi Velkou Moravou a raněstředověkými Čechami za názor v současnosti převažující (s. 216). Podobně k výkladům, bez pochyb podávaným, o významu slova sclavonicus v Kosmově době (s. 221-222) by stálo zato přečíst si starého Havránka (1925).

Hlavní problém ale spočívá zjevně v tom, že autor pojímá slovanství př́liš silně jako společenství stejné mentality, kultury, dějin, politiky apod. a týkající se všech Slovanů, a jeho 
existenci pak popírá. Vlastně je to zrcadlový obraz německého antislavismu, autorem pěkně vylíčeného (s. 25-34): němečtí antislavisté tvrdili, že toto společenství existuje (a hodnotili je negativně); autor tvrdí, že toto společenství neexistuje (a „zachraňuje“ tak v očích německé veřejnosti čest slovanských národů). Ale vtip je v tom, že pojem slovanství nebo slovanské blízkosti skutečně existuje, ale není to tak silný koncept či sociální jev, jak mysleli němečtí antislavisté a jak to k uznání jeho existence požaduje autor: slovanství se vždy definovalo (at́ už explicite nebo implicite) jazykově, protože povědomí o blízkosti Slovanů se vždy rovnalo povědomí o blízkosti jazyka, přičemž ovšem z jazykové blízkosti vyplývají nemalé implikace jazyk přesahující, jak svého času - a v tomto případě bezpečně - ukázal Jakobson (1985, 1-64). Autor sice v samém závěru (s. 440-441) výchozí jazykovou definici slovanství zmiňuje a dokonce mezi literaturou tuto definici podporující cituje Jakobsona, ale ony mimojazykové implikace nediskutuje. Ostatně podobně jako s Jakobsonem by bylo bývalo třeba se vyrovnat s velkým picchiovským konceptem Slavia orthodoxa, postulujícím jistý slovansky definovaný, ale jazyk přesahující celek; v knize o tomto konceptu nepadne ani slovo (ačkoli se onen celek, ovšem nejmenován, v závěru na s. 444 poněkud disparátně připomene).

Obecně se navíc zdá, že autor myslí v absolutních kategoriích bud'-anebo, a jaksi mu tak uniká intelektuální povaha většiny sociálních pojmů, které nemusejí nutně recipovat všichni členové komunity, na něž se dané pojmy vztahují, ani nemusejí nutně být vztahovány na všechny jednotlivce, na které by vztahovány být mohly (je to sice poněkud překryto autorovým odkazováním na andersonovskou imagined community, jíž má být i Slovanstvo, ale byt má imagined community zdání či pověst pojmu relativizujícího absolutizace a generalizace, je to pojem postavený na představě o existenci eficientních sil skrytých a skutečně sociálně relevantních - absolutních a obecných). Konkrétně pak autor nedoceňuje dialektickou a dynamickou povahu kategorie slovanství: intelektuálové starající se o slovanství reflektovali sebe dialekticky zároveň jako př́slušníky jednotlivých národů i jako Slovany, a tato dvojitá reflexe se dynamicky uplatňovala podle konkrétní situace (ve smyslu Jakobsonovy 2014, 480 „zájmové pospolitosti slovanské“).

Jako př́lklad hledanosti i obecné povahy autorovy argumentace můžeme zmínit, že proti tomu, že cyrilometodějský jazykově-kulturní podnik byl konstituentem slovanské identity, poukazuje na to, že tento podnik byl určen jen pro Moravany, ale ne pro všechny Slovany (s. 169-170). Samozřejmě nelze tvrdit, že byl určen také pro Slovany sedící tehdy na Dněpru, jak by chtěl autor; o těch bratří nejspíš ani nevěděli a jistě nevěděli ani Slované na Dněpru o našich bratřích. Ale je rozdíl mezi určením aktuálním a potenciálním: aktuálně Konstantin a Metoděj pracovali pro Rastislavovy Moravany, ale potenciálně pro všechny ostatní národy, které přirozeně rozumějí jazyku jejich textů a které oslovují v Proglase (slyšite slověnıskъ narodъ vъsъ) a jimž papež posílá Metoděje v osmé kapitole jeho Života (vъsěmъ stranamъ těmъ slověnıskyimъ); slovem slověnıskъ sotva rozuměli jen kleriky jimi vzdělané v protikladu ke klerikům latinským, jak se autor domnívá.

Kromě těchto naznačených hlavních obtíží nacházíme v knize různé rušivé doprovodné věci. Obecně jsou to časté chyby ve slovanských slovech a jménech, které ovšem u německých historiků tzv. Východní Evropy (tj. de facto bývalého východního bloku) nacházíme 
nezř́dka. Neumím si představit takové chyby u německých historiků románských nebo anglosaských zemí, nebo by u nich myslím alespoň byly pokládány za povážlivou odbornou diskvalifikaci. Patrně se zde odráží odlišný status „východoevropských“ národů v německé společnosti. Konkrétně pak narážíme na různé drobnosti nebo vedlejší problesknutí stereotypů nebo nereflektovaností. Tak v časovém rozvrhu pojednání o novodobém slavismu se jako milník uvádí přistoupení k EU (s. 34); to je ale zjevně jen německá perspektiva: členství v EU, příp. tzv. evropanství funguje v německých intelektuálních kruzích jako identitotvorná náhražka za potlačované němectví. Masaryk a Beneš, sotva náležející do jedné intelektuálně-politické kategorie, jsou oba - jakoby v sudetoněmecké perspektivě - spojeni a označeni za neoslavisty (s. 35). Když čteme, že Lužičtí Srbové byli v 19. století téměř zcela asimilováni a cítili se jako říšskoněmečtí občané (s. 29) a že titíž si sice až dodnes uchovali svůj jazykově-kulturní svéráz, ale jejich snaha konstituovat se jako samostatný národ byla neúspěšná (s. 326, pozn. 1039), jako bychom četli starého bojovného německého vlastence Dielse (1963, 241). Závěr oddílu o německém antislavismu (s. 34) je, obávám se, př́liš optimistický: negativnímu obrazu východoevropských sousedů se sice po roce 1989 nedává etiketa die Slawen, ale jak ukazuje nověji např́klad německá publicistika za tzv. uprchlické krize, naznačující bezcitnost východních sousedů, negativní obraz je v určitých kruzích stále přítomen.

Přes to, co bylo výše vytčeno, knihu doporučujeme k pozornosti; sice asi nic nového poučenému čtenáři nepřinese, ale je tam jaksi utříděn materiál (včetně bohaté sekundární literatury, k níž bychom za jazykovědce doplnili alespoň Bočka 2014 a Skach 2015) a může také posloužit metahistoriograficky jako jeden z objektů pro práce o německém vidění zemí na východ od Německa.

\section{LITERATURA}

BočEK, Vít. 2014. Praslovanština a jazykový kontakt. Praha: Lidové noviny.

Diels, Paul. 1963. Die slavischen Völker. Wiesbaden: Otto Harrassowitz.

HAVRÁNEK, Bohuslav. 1925. K názvům lingua sclavonica, boëmo-slavica = český jazyk a Sclavus, Slavus = Čech, Slovák. Listy filologické 52, 111-120.

JaKobson, Roman. 1985. Selected Writings. VI. Rudy, Stephen, ed. Berlin - New York -Amsterdam: Mouton.

Jakobson, Roman. 2014. Selected Writings. IX (2). Toman, Jindřich, ed. Berlin - Boston: De Gruyter Mouton.

SкACH, Elisabeth. 2015. Die Lautgeschichte des mittelalterlichen Slavischen in Griechenland. Frankfurt am Main: Peter Lang. 


\section{Bohumil Vykypěl}

Czech Language Institute of the CAS, v. v. i.

\section{Veveří 97, 602 oo Brno}

Czech Republic

vykypel@ujc.cas.cz

Toto dílo lze užít v souladu s licenčními podmínkami Creative Commons BY-NC-ND 4.0 Internationa (https://creativecommons.org/licenses/by-nc-nd/4.o/legalcode). Uvedené se nevztahuje na díla či prvky (např. obrazovou či fotografickou dokumentaci), které jsou v díle užity na základě smluvní licence nebo výjimky či omezení př́slušných práv. 